\title{
SLOVAK HOUSING ESTATES AND THE ACCESSIBILITY OF THE KEY AMENITIES. CASE STUDY BANSKÁ BYSTRICA
}

\begin{abstract}
Housing estates, which have emerged during the post-war mass housing development, became the significant part of an urban structure of many cities across the eastern bloc. In Slovak cities, they still represent the major part of residential complexes. Housing estates usually ignored the original urban structure and isolated themselves declaring their independence from the rest of the city. In an effort to a strict functional segregation housing estates paradoxically became dependent on the traditional urban structure. The original plans of the housing estates mostly proposed the local centers with a relatively broad spectrum of amenities; however, these were often greatly reduced or unfinished under the pressure of solving housing problems. Since the functional mixing with an emphasis on the walking accessibility of the key amenities from the place of a residence is one of the important aspects of livable and sustainable neighborhoods, the questions arises: To what extent do housing estates provide the key amenities necessary for the everyday life of their inhabitants? Are they in this respect truly self-sufficient or fail to fulfill their original ambition? Answering these questions is important not only in terms of the evaluation of their quality but also for setting strategies for the further development of housing estates (for example, intensification).

The goal of the paper was to examine the current structure of Slovak housing estates in terms of accessibility of the key amenities and the evaluation of the results from the perspective of the future development of housing estates. The research was carried out within 18 selected housing estates of varying size, nature and location within the city of Banská Bystrica (county city in Central Slovakia). The key amenities and optimal walking distances (radius of accessibility) were defined based on a comparison of existing researches and recommendations. Within the territory of housing estates, the percentage of overall coverage by key amenities (percentage of the territory of the individual housing estate with access to all key amenities in walking distance), the average percentage of coverage of the key amenities and the percentage of coverage of the selected key amenities were assessed. The results of the research demonstrate a large diversity of housing estates in terms of accessibility of the key amenities and their relation to other features of housing estates.
\end{abstract}

Keywords: Housing estate, accessibility, amenities, walking distance, intensification, Slovakia, Banská Bystrica. 


\section{Introduction}

In the second half of the $20^{\text {th }}$ century, mass housing construction has become a phenomenon that has permanently changed the face of European cities. This concept was firmly rooted especially in the countries of the former Eastern Bloc because it perfectly fitted into the functioning of the planned economy. Also in Slovakia, despite a growing criticism, mass housing construction, represented by "sídliska'" (housing estates), were emerging until the 1990s. Thus, the housing estates in the Slovak Republic became a dominant form of the urban residential structure associated with many specific problems of functional-operational, mass-spatial, technical and socio-economic nature. Currently, the housing estates represent one of the most discussed issues in the field of architecture and urban planning. The specific topic of the housing estates is their completion or so called process of intensification. This can be understood as a process involving all interventions in the structure of housing estates which contribute to increasing its efficiency or try to maximize its use. The key issue of intensification is finding its optimal proportions and forms depending on a number of factors. One of these factors is the accessibility of key amenities that creates potentials or limits the possibilities of further development of the housing estates.

\section{Theoretical background}

The functional-operational structure of the residential area is (together with the mass-spatial, social and economic structure) one of the determining aspects of the creation of a sustainable city. As the key features of the functional-operational structure can be considered the accessibility of amenities (except for basic amenities, also higher and specific amenities), accessibility of jobs, interconnection of complementary functions (for example a café with a patio by a playground), good transport connection (walking, cycling, public transport), reducing the burden of car traffic, introduction of innovative forms of transport and others (Stangel 2013). O. Melcerová (2013) emphasizes, in particular, a sufficient mix of functions within a residential complex (approximately $500 \mathrm{~m}$ ). According to B. Komar (2014), optimal state of the housing estate in terms of civic amenities is reflected by its even distribution, quantity and a variety of shops and services providing alternative options for residents. Based on these statements it can be said that from a functional-operational point of view, a varied and evenly distributed network of amenities (especially key amenities) with efficient transport links is crucial.

Among the forms of transport ensuring accessibility of amenities, a pedestrian transport with a good connection to public transport is decisive. Urban Task Force (2005) pays close attention to the issue of efficient spatial planning, highlighting 
in particular the need to create a hierarchical and well-connected network of urban local centers (with amenities) serving the territory in a certain amount of time - from local centers (up to 2 minutes' walk) through quarter centers (5 minutes' walk) and the city center (within 20 minutes' walk). A specific attention to pedestrian movement pays J. Gehl (2012) who set the average distance that people are still willing to walk on at $500 \mathrm{~m}$ (about 5 minutes' walk). Despite the fact that in the literature (Bartková, Vyšinka 1980; Kavan 1983; Urban Task Force 1999; Komar 2014) we can find differently defined optimal walking distances to civic amenities, in principle it can be stated that the average distance to the key amenities is actually around $500 \mathrm{~m}$. Under the key amenities, we understand mainly basic amenities - the amenities of everyday use that should be located within the walking distance from the place of residence. Based on the aforementioned authors (Bartková, Vyšinka 1980; Kavan 1983; Urban Task Force 1999; Komar 2014), a list of key amenities (bus stop, primary school, kindergarten, post office, park, groceries, doctor, local center and others) can be derived.

In the market economy, the priority is given to a detailed analysis of the needs of a territory or, in other words, to the demand analysis. In the planned economy (until 1989) standards, norms and indicators played a key role (Vitková 2008). The so-called technical and economic indicators also played a crucial role in the planning of deployment of civic amenities. According to Z. Rothbauer (2014), a number of schools, kindergartens, shops, services or cultural amenities were defined in terms of quantity per flat. In this way, the optimal accessibility of both basic and higher civic amenities should be theoretically ensured. Housing estates also referred to as "komplexná bytová výstavba" (complete housing construction), should have been self-sufficient and independent from the city itself (Moravč́́ková et al. 2011). But the construction of housing estates was not fully in line with the plans. Decisive criterion of successful development was the number of finished flats, while other aspects of development were often forgotten. L'. Vitková, K. Görner (2016) point to the large differences between the original plans and their implementation, especially, in terms of amenities, infrastructure and public spaces. In the context of current efforts to complete the structure of housing estates, it is necessary to examine the real ability of a housing estate to provide the key amenities for its inhabitants within the range of pedestrian accessibility and thus to determine the optimum form of further development of the housing estate.

In terms of intensification, the accessibility of key amenities is one of the basic potentials but also the limits of the territory. One of the pillars of the sustainable compact urban structure is its multi-functionality - good coverage of the amenities within walking distance. While a well-covered territory creates prerequisites for further development, intensification of underdeveloped territory could result into creation of unsustainable neighborhood dependent on the other city structures. This is especially dangerous when we consider that in the current market economy, 
an increase in key amenities is not automatically guaranteed together with an increase in population (it concerns mainly less cost-effective or non-profit-making amenities such as primary schools, kindergartens, parks and the like). From this point of view, the process of intensification should be concentrated mainly on housing estates with a well-built network of key amenities, or on the completion of key amenities in the housing estates with a perspective of future development.

\section{Methodology}

Case study: Research of the accessibility of key amenities was carried out on a sample of 18 housing estates within the county city of Banská Bystrica (around 80000 inhabitants). The selected city has undergone extreme growth during the period of mass housing construction. During the period 1950-1991, the number of inhabitants increased more than six times and Banská Bystrica moved in the hierarchy of Slovak cities from the $14^{\text {th }}$ to the $5^{\text {th }}$ place (actually $6^{\text {th }}$ ). The structure of the city (with the exception of the historical core and the associated rural settlements) is dominated by housing estates. In Banská Bystrica, it is possible to find a variety of housing estates with a typical structure for the $50^{\text {th }}$, $60^{\text {th }}, 70^{\text {th }}$ and $80 \mathrm{~s}$ of the $20^{\text {th }}$ century, which represents a wide range of diverse housing estates. A number of diverse housing estates within a coherent area and the middle size of the city are making the city of Banská Bystrica one of the best case study choices corresponding to research needs.

Key amenities: The key amenities were selected on the basis of the theoretical background (Bartková, Vyšinka 1980; Kavan 1983; Urban Task Force 2005; Komar 2014) based on the most frequently mentioned local amenities: bus stop, primary school, kindergarten, post office, park, grocery, local center, doctors (general practitioner for children and adults).

A park was defined by J. Komrska (2009) as a public space with greenery and amenities for short-term relaxation and sport-recreational activities that do not disturb relaxing people. An area of the park should be at least 0.5 ha. The local center is understood as a public space with adjacent buildings (it can also be single building) in which at least the following amenities are concentrated: shops, gastronomy, services.

Optimal accessibility: In terms of accessibility, the emphasis was placed on walking distance. According to J. Gehl (2012), about 5 minutes of walking $(500 \mathrm{~m})$ was considered to be a walking maximum. Regarding accessibility of kindergartens, at which authors pointed to significantly lower walking distance: R. Bartková, J. Vyšinka (1980) 250-500 m, J. Kavan (1983) up to 400 m and B. Komar (2014) $200 \mathrm{~m}$, this criterion was tightened to 250 meters. As the territory 
with a full accessibility of the selected amenity was considered a territory, which was located in the range of $500 \mathrm{~m}(250 \mathrm{~m})$ circuit from the selected amenity.

The selected key amenities within the city were identified using two complementary methods. In the first step, the internet map applications (Google Maps, OpenStreetMap) were used to identify the key amenities within the city. In the second step, the recency of the data collected was verified by the Google search engine and the field survey. All identified key amenities were drawn on a digital map using the AutoCAD software. To specify the range of coverage of the identified key amenities the circles with the centers in key amenities were created.

Three aspects of accessibility of key amenities were monitored individually in all selected housing estates:

1. Percentage of overall coverage by key amenities (percentage of the territory of the individual housing estate with access to all key amenities within walking distance).

2. Average percentage of coverage of key amenities.

3. Percentage of coverage of selected key amenities.

The coverage of a single key amenity (for example school) within the housing estate was represented by the total area of housing estate overlapping with the circles which have the centers in the position of the key amenities (in this case schools) and the radius of $500 \mathrm{~m}$ ( $250 \mathrm{~m}$ in the case of kindergartens). The coverage was expressed in percentage instead of the real area to make it more comparable. Percentage of overall coverage by key amenities represented the percentage of the area of housing estate covered by all selected key amenities. The average percentage of coverage of key amenities was represented by an average of percentages of coverage of all selected amenities within the housing estate. Percentage of coverage of selected key amenities represented the overview of percentages of coverage of all selected amenities within the housing estate.

To better describe the results, the percentage rating was scaled $(0-24 \%, 25-49 \%$, $50-74 \%, 75-100 \%)$. Interpretation of the results was carried out on the basis of comparison of results, average assessments of individual aspects and comparison of results with selected characteristics of settlement (area, population). For a more accurate and simpler evaluation of relations between variables, there was a used correlation analysis. Pearson's correlation coefficient was calculated using Microsoft Excel 2010 (fx CORREL function). Statistically significant correlation coefficients $\mathrm{R}$ (greater than $0.5 /$ less than -0.5 ) were taken into account. Just the findings evaluated as the most relevant from the point of view of research are mentioned in the results. 


\section{Results and discussion}

The highest percentage of overall coverage by key amenities was recorded in housing estates Sásová II (59.9\%) and Rudlová II (58.8\%) (Fig. 1). Housing estates Fončorda Mládežnícka (45.8\%) and Fončorda Tulská (45.3\%) have approached the $50 \%$. The lowest percentage of $0 \%$ of overall coverage by key amenities was recorded in the housing estates Bakossova, Uhlisko, Trieda Hradca Králové, Král'ová, Mateja Bela (Fig. 2), Rudlová-Sásová I and Severná. Fig. 3 shows the overall coverage by key amenities within the city of Banská Bystrica.

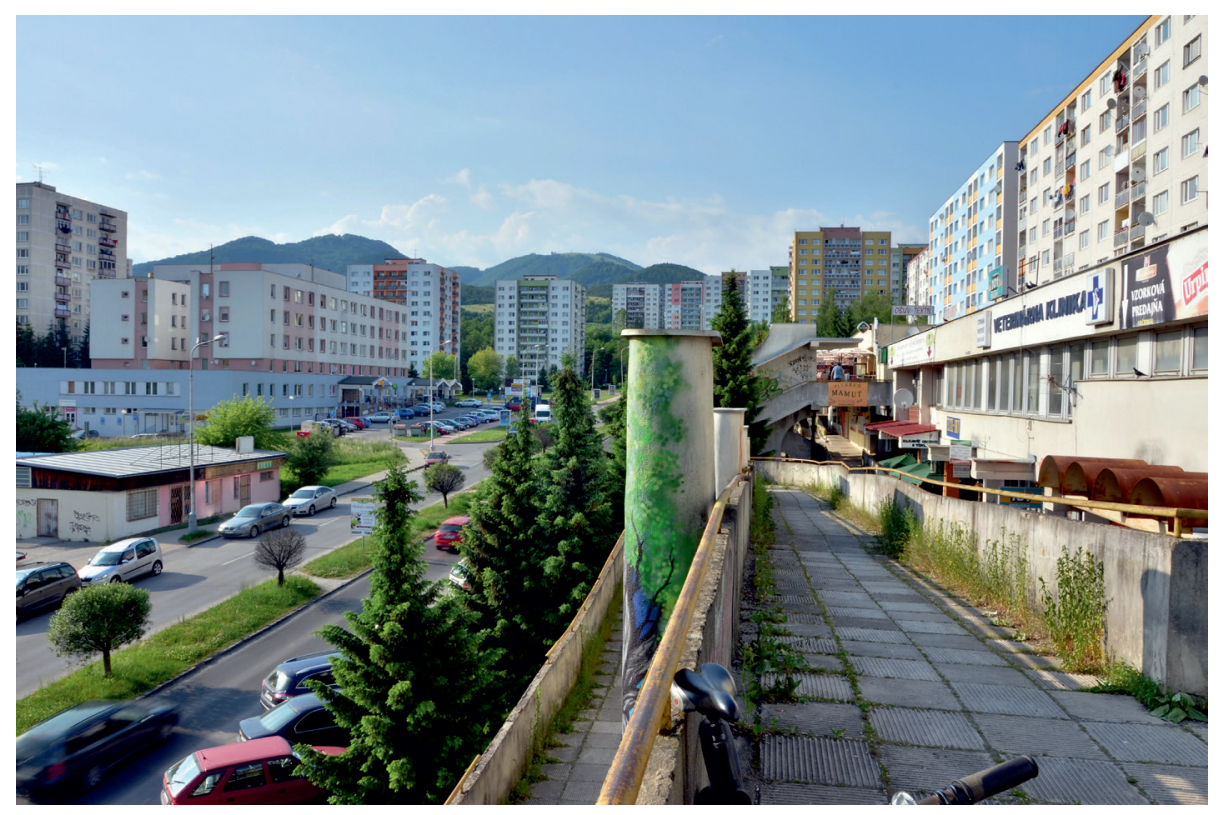

Fig. 1. The central axis of housing estate Rudlová-Sásová II includes many of the key amenities

\section{photo: K. Görner}

Significantly better than percentage of overall coverage by key amenities was average percentage of coverage of key amenities where the coverage of $75 \%$ was overcome in 9 housing estates - Fončorda Mládežnícka (90.85\%), Podlavice (90.6\%), Sásová II (88.6\%), Rudlová II (87.3\%), Fončorda Tulská (86.8\%), Sídlisko SNP (81.7\%), Radvaň (77.76\%), Fončorda Internátna (77.7\%) and Fortnička (75.1\%). The lowest recorded average percentage of coverage of key amenities was not in any housing estate lower than 25\% - Král'ová (35.8\%), Mateja Bela (37.7\%), Severná (39.1\%), Uhlisko (46\%), Rudlová-Sásová I $(46.15 \%)$. 


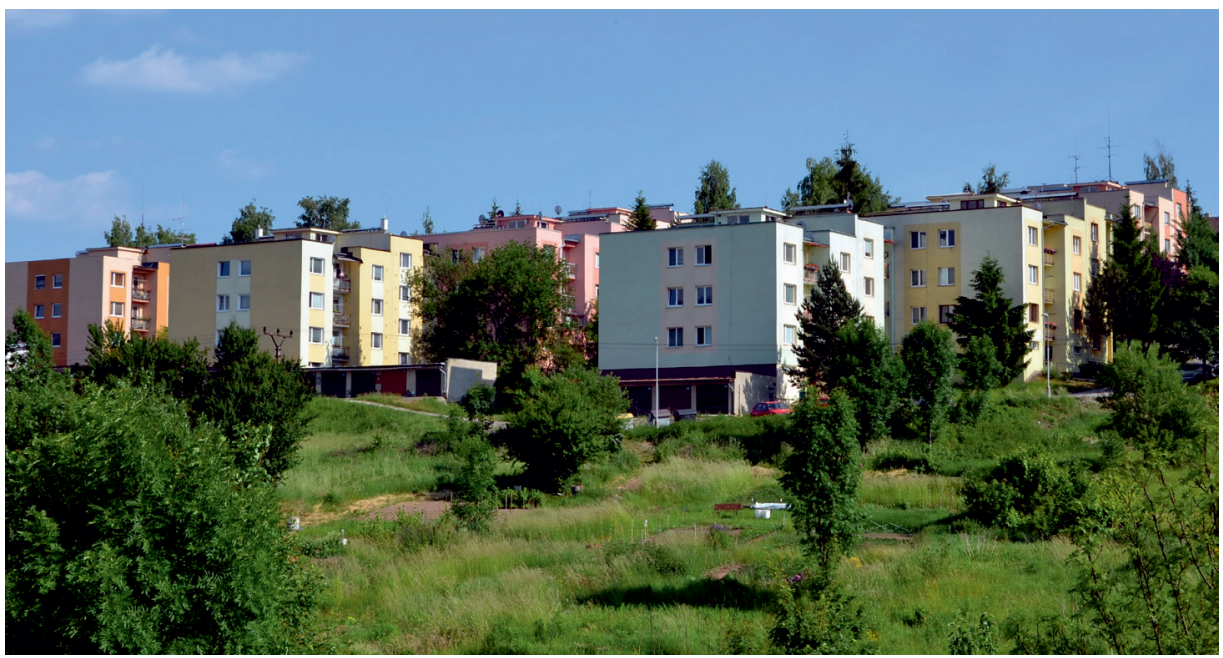

Fig. 2. Housing estate Mateja Bela located eccentrically to urban development axes is one of the housing estates with the worst accessibility of the key amenities

\section{photo: K. Görner}

Among the key amenities, the best percentage of coverage of selected key amenities in average was achieved by public transport $(100 \%)$ and groceries $(98 \%)$. A little worse coverage in average had primary schools $(74 \%)$, doctors $(68.9 \%)$, parks $(60.7 \%)$, and local centers $(60.4 \%)$. The worst result with coverage lower than $50 \%$ had kindergartens $(42.4 \%)$ and post offices $(40.3 \%)$. Coverage of individual key amenities within the surveyed area is shown in Fig. 4.

A summary of the results is published in the table (Table 1). Based on the analysis of the obtained data, several observations can be made. The accessibility of the key amenities within housing estates in Banská Bystrica can be generally considered as uneven. The results suggest that the higher populated housing estates are better covered by all key amenities $(\mathrm{R}=0.7)$ and therefore better meet the vision of complex housing construction (mainly housing estates Sásová II, Rudlová II, practically the entire residential complex of Fončorda and housing estate Sídlisko SNP). Exceptions are housing estates Radvaň, and Trieda Hradca Králové. The reason of low percentage of overall coverage by key amenities in housing estate Radvan̆ is, in particular, the uneven distribution of basic amenities (schools and kindergartens) as well as the poor maintenance of the greenery around the Radvanských manor which does not meet the attributes of the park. Housing estate Trieda Hradca Králové also suffers because of uneven distribution of key amenities and absence of post office within the walking distance. From a comparison of the results, it can be concluded that the population of the housing estate influences mainly the accessibility of kindergartens $(R=0.67)$, post offices 
$(\mathrm{R}=0.58)$, and local centers $(\mathrm{R}=0.52)$. In the smaller and mainly less populated housing estates, they often absent or cover only part of their territory. Interesting is also the fact, that the relationship between the accessibility of key amenities and population density (which was subsequently verified) did not confirm any statistically significant dependence.

\section{LEGEND}

Built-up area of the city

Buildings within housing estates

$\square$ Borders of housing estates

Areas of housing estates covered by all key amenities
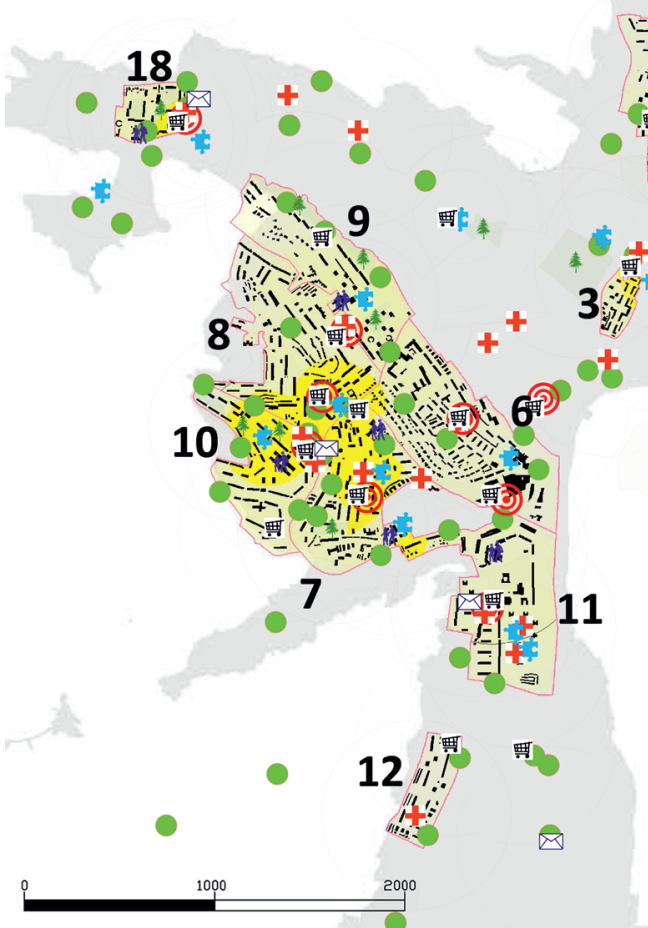

\begin{tabular}{|c|c|}
\hline & Public transport \\
\hline M & Primary schools \\
\hline+ & Kindergartens \\
\hline
\end{tabular}

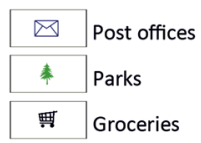

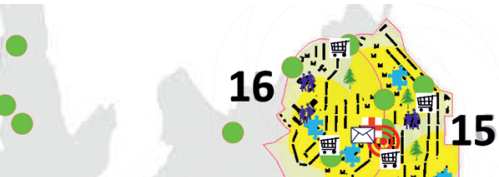

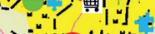

15
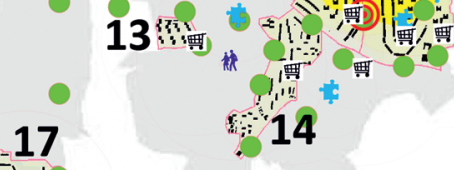

1 Sídlisko SNP

2 Bakossova

3 Fortnička

4 Uhlisko

5 Rudlovský potok

6 Stará Fončorda

7 F.-Mládežnícka

$8 \mathrm{~F}$.-Internátna

9 THK

10 F.-Tulská

11 Radvaň

12 Králová

13 Mateja Bela

14 Rudlová-Sásová I

15 Rudlová II

16 Sásová II

17 Severná

18 Podlavice

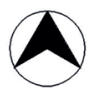

Fig. 3. The overall coverage by key amenities within the city of Banská Bystrica with highlighted individual key amenities

Source: own compilation 


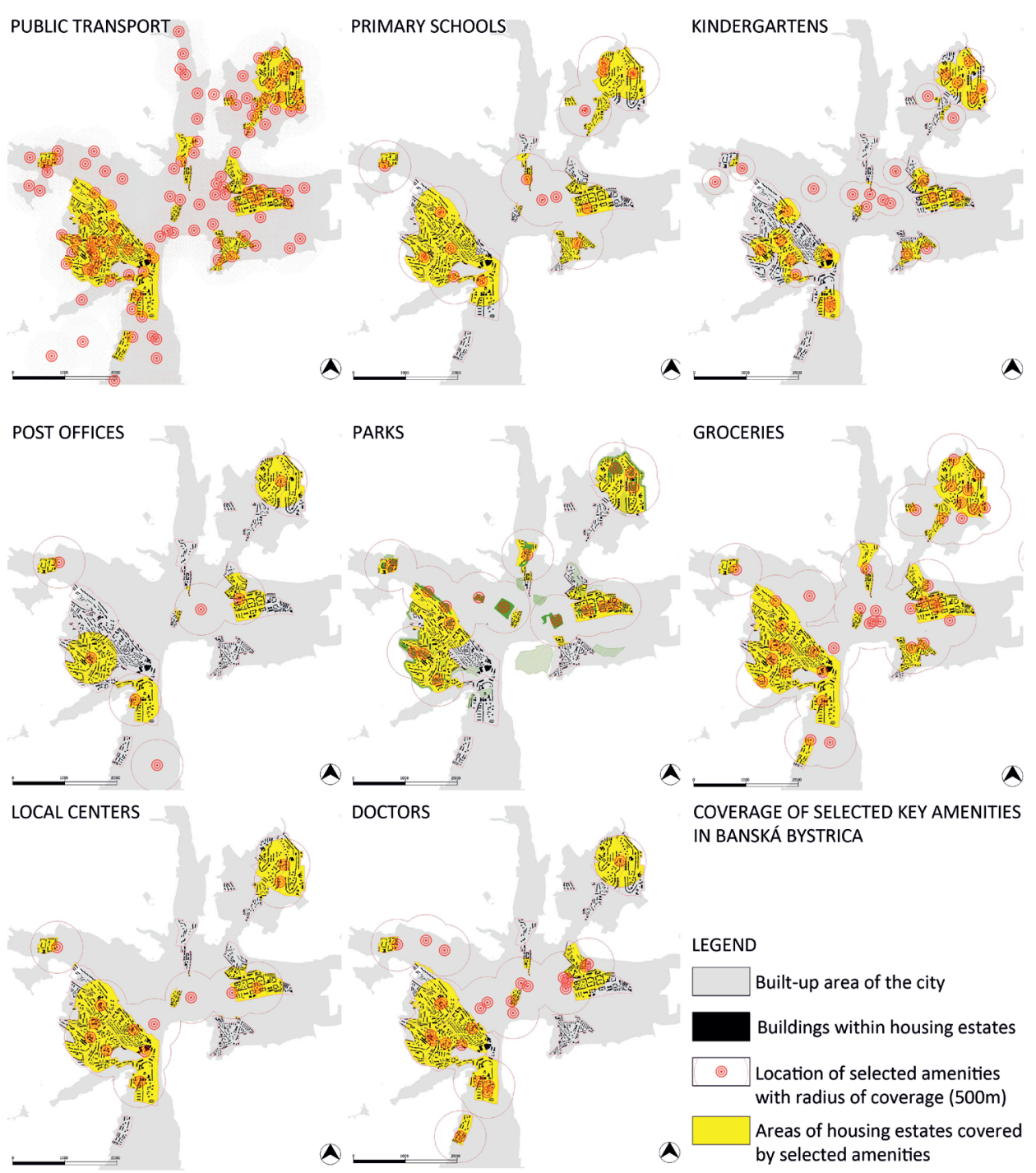

Fig. 4. Coverage of individual key amenities within the surveyed area

Source: own compilation

More significant differences between the percentage of overall coverage by key amenities and average percentage of coverage of key amenities result from uneven distribution or lower coverage of only some of the selected key amenities. In many housing estates, therefore, a significant improvement in the accessibility of key amenities would have been achieved by adding one of the key amenities. 
In some cases, it would only be to move the kindergarten to a more suitable position or to improve the current state of greenery so that it would meet the attributes of the park. Relatively low accessibility of parks can be perceived as a paradox due to the high percentage of greenery in housing estates. A low number of activities, poor maintenance of greenery and the frequent fragmentation of the green areas to the small fragments do not correspond to the size and functions of a park.

Table 1. Summary of the results of accessibility of the key amenities within the housing estates in Banská Bystrica

\begin{tabular}{|c|c|c|c|c|}
\hline $\begin{array}{l}\text { Housing } \\
\text { estate }\end{array}$ & $\begin{array}{c}\text { Area / ha } \\
\text { population }\end{array}$ & $\begin{array}{c}\text { Percentage } \\
\text { of overall } \\
\text { coverage by } \\
\text { key } \\
\text { amenities } \\
\end{array}$ & $\begin{array}{c}\text { Average } \\
\text { percentage } \\
\text { of coverage } \\
\text { of key } \\
\text { amenities } \\
\end{array}$ & Percentage of coverage of selected key amenities \\
\hline 2 Bakossova & $\begin{array}{c}6,3 \\
- \\
1047\end{array}$ & $0 \%$ & $55 \%$ & $\begin{array}{c}\text { Public transport: } 100 \% \text {; Primary schools: } 100 \% \text {; Kindergartens: } 13,9 \% \\
\text { Post offices: } 13,6 \% \text {; Parks: } 58,5 \% \text {; Groceries: } 100 \% \text {; } \\
\text { Local centers: } 4 \% \text {; Doctors: } 49,6 \%\end{array}$ \\
\hline 3 Fortnička & $\begin{array}{c}5,2 \\
- \\
928\end{array}$ & $24 \%$ & $75,1 \%$ & $\begin{array}{c}\text { Public transport: } 100 \% \text {; Primary schools: } 24,2 \% \text {; Kindergartens: } 60,1 \% \text {; } \\
\text { Post offices: } 16,6 \% \text {; Parks: } 100 \% \text {; Groceries: } 100 \% \\
\text { Local centers: } 100 \% \text {; Doctors: } 100 \%\end{array}$ \\
\hline 4 Uhlisko & $\begin{array}{c}28,6 \\
- \\
2670\end{array}$ & $0 \%$ & $46 \%$ & $\begin{array}{c}\text { Public transport: } 100 \% \text {; Primary schools: } 90,5 \% \text {; Kindergartens: } 70 \% \text {; Post offices: } 0 \% \text {; } \\
\text { Parks: } 11,8 \% \text { (pond and surroundings can be revitalized, recreational potential of Urpin } \\
\text { hill); Groceries: } 100 \% \text {; Local centers: } 4 \% \text {; Doctors: } 49,6 \%\end{array}$ \\
\hline $\begin{array}{l}5 \text { Rudlovský } \\
\text { potok }\end{array}$ & $\begin{array}{c}21,6 \\
- \\
1993 \\
\end{array}$ & $22,6 \%$ & $67,5 \%$ & $\begin{array}{l}\text { Public transport: } 100 \% \text {; Primary schools: } 39,8 \% \text {; Kindergartens: } 58 \% \text {; } \\
\text { Post offices: } 75,8 \% \text {; Parks: } 36,1 \% \text { (greenery along the Rudlovský stream can be } \\
\text { revitalized); Groceries: } 97,6 \% \text {; Local centers: } 32,1 \% \text {; Doctors: } 94,8 \%\end{array}$ \\
\hline $\begin{array}{l}7 \text { Fončorda } \\
\text { Mládežnícka }\end{array}$ & $\begin{array}{c}36,4 \\
- \\
3539\end{array}$ & $45,8 \%$ & $90,85 \%$ & $\begin{array}{c}\text { Public transport: } 100 \% \text {; Primary schools: } 100 \% \text {; Kindergartens: } 65,3 \% ; \\
\text { Post offices: } 74 \% \text {; Parks: } 90,8 \% \text {; Groceries: } 100 \% \\
\text { Local centers: } 100 \% \text {; Doctors: } 96,7 \%\end{array}$ \\
\hline $\begin{array}{l}8 \text { Fončorda } \\
\text { Internátna }\end{array}$ & $\begin{array}{c}47,8 \\
- \\
4038\end{array}$ & $30,5 \%$ & $77,7 \%$ & $\begin{array}{c}\text { Public transport: } 100 \% \text {; Primary schools: } 88,3 \% \text {; Kindergartens: } 36,9 \% ; \\
\text { Post offices: } 41,2 \% \text {; Parks: } 88,3 \% \text {; Groceries: } 95,3 \% ; \\
\text { Local centers: } 84,2 \% \text {; Doctors: } 87,3 \%\end{array}$ \\
\hline $\begin{array}{l}9 \text { Trieda } \\
\text { Hradca } \\
\text { Králové }\end{array}$ & $\begin{array}{c}35,8 \\
- \\
3412\end{array}$ & $0 \%$ & $68,8 \%$ & $\begin{array}{l}\text { Public transport: } 100 \% \text {; Primary schools: } 75,4 \% \text {; Kindergartens: } 42,4 \% \text {; } \\
\text { Post offices: } 0 \% \text {; Parks: } 100 \% \text {; Groceries: } 100 \% \text {; } \\
\text { Local centers: } 63,5 \% \text {; Doctors: } 68,9 \%\end{array}$ \\
\hline $\begin{array}{c}10 \text { Fončorda } \\
\text { Tulská }\end{array}$ & $\begin{array}{c}30,7 \\
- \\
5559\end{array}$ & $45,3 \%$ & $86,8 \%$ & $\begin{array}{c}\text { Public transport: } 100 \% \text {; Primary schools: } 95,9 \% \text {; Kindergartens: } 45,3 \% ; \\
\text { Post offices: } 83,2 \% \text {; Parks: } 100 \% \text {; Groceries: } 93,5 \% ; \\
\text { Local centers: } 85,3 \% \text {; Doctors: } 91,2 \%\end{array}$ \\
\hline $\begin{array}{l}14 \text { Rudlová- } \\
\text { Sásová I }\end{array}$ & $\begin{array}{c}14,9 \\
- \\
2276\end{array}$ & $0 \%$ & $46,15 \%$ & $\begin{array}{l}\text { Public transport: } 100 \% \text {; Primary schools: } 100 \% \text {; Kindergartens: } 25,5 \% \text {; } \\
\text { Post offices: } 0 \% \text {; Parks: } 0 \% \text {; Groceries: } 98,7 \% \text {; } \\
\text { Local centers: } 45 \% \text {; Doctors: } 0 \%\end{array}$ \\
\hline $\begin{array}{l}15 \text { Rudlová } \\
\text { II }\end{array}$ & $\begin{array}{c}43,3 \\
- \\
10505\end{array}$ & $58,8 \%$ & $87,3 \%$ & $\begin{array}{c}\text { Public transport: } 100 \% \text {; Primary schools: } 76,9 \% \text {; Kindergartens: } 86 \% \text {; } \\
\text { Post offices: } 73,4 \% \text {; Parks: } 94,3 \% \text {; Groceries: } 100 \% \text {; } \\
\text { Local centers: } 94,5 \% \text {; Doctors: } 73,6 \%\end{array}$ \\
\hline 16 Sásová II & $\begin{array}{c}44,5 \\
- \\
6721\end{array}$ & $59,9 \%$ & $88,6 \%$ & $\begin{array}{c}\text { Public transport: } 100 \% \text {; Primary schools: } 92 \% \text {; Kindergartens: } 70 \% \text {; } \\
\text { Post offices: } 89,8 \% \text {; Parks: } 83,1 \% \text {; Groceries: } 100 \% \text {; } \\
\text { Local centers: } 83,2 \% \text {; Doctors: } 90,4 \%\end{array}$ \\
\hline 17 Severná & $\begin{array}{c}13,6 \\
- \\
1164\end{array}$ & $0 \%$ & $39,1 \%$ & $\begin{array}{c}\text { Public transport: } 100 \% \text {; Primary schools: 20,3\%; Kindergartens: } 0 \% \text {; } \\
\text { Post offices: } 0 \% \text {; Parks: 100\%; Groceries: } 92,4 \% \text {; } \\
\text { Local centers: 0\%; Doctors: } 0 \%\end{array}$ \\
\hline 18 Podlavice & $\begin{array}{c}10,1 \\
- \\
1705\end{array}$ & $25,1 \%$ & $90,6 \%$ & $\begin{array}{l}\text { Public transport: } 100 \% \text {; Primary schools: } 100 \% \text {; Kindergartens: } 25,1 \% \text {; } \\
\text { Post offices: } 100 \% \text {; Parks: } 100 \% \text {; Groceries: } 100 \% \text {; } \\
\text { Local centers: } 100 \% \text {; Doctors: } 100 \%\end{array}$ \\
\hline AVERAGE & - & $19,76 \%$ & $67,72 \%$ & $\begin{array}{l}\text { Public transport: } 100 \% \text {; Primary schools: } 74 \% \text {; Kindergartens: } 42,4 \% \text {; } \\
\text { Post offices: } 40,3 \% \text {; Parks: 60,7\%; Groceries: } 98 \% \text {; } \\
\text { Local centers: 60,4\%; Doctors: } 68,9 \%\end{array}$ \\
\hline
\end{tabular}

Source: own compilation 


\section{Conclusion}

The research focused on examining the accessibility of the key amenities on the selected housing estates within the city of Banská Bystrica has led to several findings. On one hand, it pointed out the great differences between the housing estates in terms of accessibility of the key amenities and the need for an individual approach to the housing estates in the process of their completion. On the other hand, the research indicated some relations between the accessibility of the key amenities and the character of the housing estate. Housing estates with a higher population within the surveyed sample showed better accessibility of the key amenities. Although this fact would still be appropriate to verify on a larger sample of the housing estates, this finding seems logical with regard to their construction. The larger number of inhabitants, due to the technical and economic indicators, forced more investments in amenities, while in the housing estates with a lower population some amenities were completely missing or covered by the amenities built in the surroundings (within another housing estate or other urban structure). Some of the housing estates even lacked a local center that should be the basis of every residential complex. Thus it can be said that in terms of availability of the key amenities the housing estates failed to fulfill the vision of functional-operational independent urban structures. The needs of the residents of the housing estates are often supplemented by an inner city or by housing estates with the better accessibility of key amenities. This is ensured by relatively good coverage by public transport. With the current tendency of intensification of the structure of housing estates and its organic connection with the other urban structures, it is necessary to take into account the individual ability of the housing estates to ensure the accessibility of the key amenities for new residents, workers or visitors. In housing estates with low coverage of the key amenities, the completion of the lacking key amenities should be a condition of further development.

The objectivity of the research would be increased by its verification on a larger sample of housing estates in different cities and regions. It could be also beneficial to add other key amenities to the research (playgrounds, sports facilities, cultural facilities, community centers, churches etc.) which were not included in this research.

\section{Bibliography}

Bartková R., Vyšinka J., 1980, Zonálni struktury, SNTL, Brno.

Gehl J., 2012, Města pro lidi, Partnerství, Brno.

Kavan J., 1983, Zonálne štruktúry, SVŠT, Bratislava.

Komar B., 2014, Współczesna jakość spółdzielczej przestrzeni osiedlowej w świetle zasad rozwoju zrównoważonego na wybranych przykładach, Wydawnictwo Politechniki Śląskiej, Gliwice. 
Komrska J., 2009, Hladanie optimálneho podielu zelene v urbanistickej štruktúre, [in:] Rakšányi P., Coplák J. (eds.), Plánovanie ekologických sídlisk, ROAD, Bratislava: $72-87$.

Melcerová O., 2013, Potenciály polyfunkčného rozvoja sidlisk ilustrované na príklade sidliska Dúbravka v Bratislave a Prosek v Prahe, „Alfa”, 4: 42-53.

Moravčíková H. et al., 2011, Bratislava: atlas sídlisk, Slovart, Bratislava.

Rothbauer Z., 2014, Zdeňek Rothbauer on Work between Indicators, [in:] Hejl M. et al.,

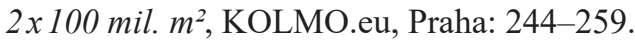

Stangel M., 2013, Kształtowanie współczesnych obszarów miejskich w kontekście zrównoważonego rozwoju, Wydawnictwo Politechniki Śląskiej, Gliwice.

Urban Task Force, 2005, Towards an Urban Renaissance, Taylor \& Francis, London.

Vitková L., 2008, Úvod do problematiky urbanistických ukazovatel'ov význam a charakteristika ukazovatel'ov, [in:] Vitková L'. (ed.), Kvantitatívne parametre urbanistických štruktúr, Road, Bratislava: 5-7.

Vitková L'., Görner K., 2016, The Strength and Degradation of Mass Housing Concepts in Slovakia, $3^{\text {rd }}$ International Multidisciplinary Scientific Conference on Social Sciences and Arts SGEM 2016, Conference Proceedings Book 4, STEF92 Technology Ltd., Sofia: $463-470$.

\section{SLOWACKIE MIESZKALNICTWO BLOKOWE A DOSTĘPNOŚĆ DO PODSTAWOWYCH WYGÓD. PRZYKLAD BAŃSKIEJ BYSTRZYCY}

Zarys treści: Osiedla, które powstały po II wojnie światowej stały się istotną częścią miejskiej struktury wielu miast bloku wschodniego. W słowackich miastach nadal stanowią one znaczną część kompleksów mieszkalnych. Osiedla te zazwyczaj ignorowały pierwotną strukturę miejską i izolowały się od niej, deklarując niezależność od reszty miasta. Paradoksalnie, dążąc do ścisłej segregacji funkcjonalnej, osiedla stały się zależne od tradycyjnej struktury miejskiej. Pierwotne plany osiedli mieszkaniowych najczęściej zakładały lokalne centra o stosunkowo szerokiej dostępności usług; jednakże w praktyce planowane inwestycje o charakterze usługowym były realizowane w mniejszym wymiarze lub niedokończone, ponieważ w pierwszej kolejności rozwiązywano problemy mieszkaniowe. Aby tereny mieszkaniowe były przyjazne dla mieszkańców, ich struktura funkcjonalna powinna być zróżnicowana, zapewniając dostęp do usług. Zatem można postawić następujące pytania: W jakim stopniu osiedla zapewniają dostęp do podstawowych usług niezbędnych do codziennego życia ich mieszkańców? Czy w tym względzie osiedla są naprawdę samowystarczalne? Odpowiedź na te pytania jest ważna nie tylko pod względem oceny ich jakości, ale także w celu ustalenia strategii dalszego rozwoju osiedli mieszkaniowych (na przykład intensyfikacji).

Celem artykułu było zbadanie aktualnej struktury słowackich osiedli pod kątem dostępności do usług oraz ocena perspektyw przyszłego rozwoju osiedli. Badania przeprowadzono w 18 wybranych osiedlach o różnej wielkości, charakterze i lokalizacji w mieście Bańska Bystrzyca (miasto powiatowe w środkowej Słowacji). Dostępność do podstawowych usług i optymalne odległości piesze (promień dostępności) zostały określone na podstawie porównania istniejących badań i zaleceń. Ocenie poddano ogólną dostępność według podstawowych usług (odsetek terenu pojedynczego osiedla z dostę- 
pem do wszystkich podstawowych usług w odległości spaceru), średni odsetek pokrycia podstawowymi usługami i procent pokrycia wybranymi usługami. Wyniki badań wskazują na dużą różnorodność osiedli pod względem dostępności usług i ich związku z innymi cechami osiedli mieszkaniowych.

Słowa kluczowe: Osiedle mieszkaniowe, dostępność, udogodnienia, odległość, intensyfikacja, Słowacja, Bańska Bystrzyca.

Karol Görner, PhD Eng. Arch. Institute of Urban Design and Planning Faculty of Architecture Slovak University of Technology in Bratislava (Slovakia) e-mail: karol.gorner@stuba.sk 